\title{
Risk factors for domestic physical violence: national cross-sectional household surveys in eight southern African countries Neil Andersson*1, Ari Ho-Foster ${ }^{2}$, Steve Mitchell ${ }^{2}$, Esca Scheepers ${ }^{3}$ and Sue Goldstein ${ }^{3}$
}

Address: ${ }^{1}$ Centro de Investigación de Enfermedades Tropicales (CIET), Universidad Autónoma de Guerrero, Acapulco, México, ${ }^{2}$ CIET Trust, 71 Oxford Road, Saxonwold 2193, South Africa and ${ }^{3}$ Soul City Institute for Health and Development Communication, 2nd Floor Park Terrace, Parktown, Johannesburg, South Africa

Email: Neil Andersson* - neil@ciet.org; Ari Ho-Foster - ari@ciet.org; Steve Mitchell - steve@ciet.org; Esca Scheepers - esca@arkonline.org; Sue Goldstein - suegold@soulcity.org.za

* Corresponding author

Published: 16 July 2007

BMC Women's Health 2007, 7:II doi:10.1 I86/1472-6874-7-II
Received: 22 August 2006

Accepted: 16 July 2007

This article is available from: http://www.biomedcentral.com/I472-6874/7/II

(c) 2007 Andersson et al; licensee BioMed Central Ltd.

This is an Open Access article distributed under the terms of the Creative Commons Attribution License (http://creativecommons.org/licenses/by/2.0), which permits unrestricted use, distribution, and reproduction in any medium, provided the original work is properly cited.

\begin{abstract}
Background: The baseline to assess impact of a mass education-entertainment programme offered an opportunity to identify risk factors for domestic physical violence.

Methods: In 2002, cross-sectional household surveys in a stratified urban/rural last-stage random sample of enumeration areas, based on latest national census in Botswana, Lesotho, Malawi, Mozambique, Namibia, Swaziland, Zambia and Zimbabwe. Working door to door, interviewers contacted all adults aged 16-60 years present on the day of the visit, without sub-sampling. 20,639 adults were interviewed. The questionnaire in 29 languages measured domestic physical violence by the question "In the last year, have you and your partner had violent arguments where your partner beat, kicked or slapped you?" There was no measure of severity or frequency of physical violence.
\end{abstract}

Results: $14 \%$ of men (weighted based on $1,294 / 8,113$ ) and $18 \%$ of women (weighted based on $2,032 / I I, 063)$ reported being a victim of partner physical violence in the last year. There was no convincing association with age, income, education, household size and remunerated occupation. Having multiple partners was strongly associated with partner physical violence. Other associations included the income gap within households, negative attitudes about sexuality (for example, men have the right to sex with their girlfriends if they buy them gifts) and negative attitudes about sexual violence (for example, forcing your partner to have sex is not rape). Particularly among men, experience of partner physical violence was associated with potentially dangerous attitudes to HIV infection.

Conclusion: Having multiple partners was the most consistent risk factor for domestic physical violence across all countries. This could be relevant to domestic violence prevention strategies.

\section{Background}

Domestic violence - also known as intimate partner abuse, family violence, wife beating, battering, marital abuse, and partner abuse - is an international prob- 
lem[1,2]. Domestic violence is not a single behaviour but a mix of assaulting and coercive physical, sexual, and psychological behaviours designed to manipulate and dominate the partner to achieve compliance and dependence. Women are more likely to experience physical injuries or psychological consequences[3,4].

Domestic violence is well documented in several African countries. In eastern Nigeria, a clinic-based survey of 300 women reported $40 \%$ had experienced violence in the previous year[5]. In one district of Uganda, 30\% of 5,109 women attending a clinic had received threats or physical abuse. The majority of respondents viewed wife beating as justifiable in some circumstances[6]. In Durban, South Africa, more than one third of women from a low-income community had experienced domestic violence at some stage[7]. A South African study reported domestic violence associated with violence in childhood, education and multiple partners[8,9]. In southern Africa domestic violence is particularly important because of the multiple links between violence and HIV infection[10]. Links between domestic violence and HIV have been reported in Botswana[11], Ghana[12], Malawi[13], South Africa[14], Tanzania[15], Uganda[16,17], Democratic Republic of Congo[18] and Zambia[19].

This is a baseline assessment of attitudes and practices, from which we intend to measure the impact of mass media campaigns, launched since the baseline by Soul City. The survey content was thus geared to measure the impact of education-entertainment messages[20], rather than as a specific research hypothesis. One section of the questionnaire dealt with domestic violence - attitudes and subjective norms, collective efficacy, discussion of the issue and experience of physical domestic violence in the last year - and the results are reported here as a cross-sectional survey.

\section{Methods}

\section{Design}

In Botswana, Lesotho, Swaziland, Malawi, Mozambique, Namibia, Zambia and Zimbabwe we stratified the most recent available census into rural, urban (not within the capital region), and urban capital sites. In each country, we drew a last stage random selection of enumeration areas, with probability proportional to the national population (Table 1).

\section{Training and fieldwork}

After training, coordinators translated, back-translated and piloted the common instruments in 29 languages: Afrikaans, Bemba, Changana, Chichewa, Chindali, Chitimbuka, Chona/Shona, Chope, English, Herero, Kalanga, Kaonde, Kwangali, Lozi, Luvale, Mucua, Ndau, Ndebele, Nyanja, Oshiwambo, Portuguese, Ronga, Sena, Sesotho, Seswati, Setswana, Shangaan, Xitshwa and Xitsonga. Each field team of seven or eight interviewers visited approximately 10 communities, one per day. Interviewers tried to cover all households in each enumeration area, without sub-sampling. In each household, they interviewed all adults aged 16-60 years present at the time of the visit.

\section{Ethical considerations}

An accredited international ethical review board evaluated the proposal, noting concerns that disclosure might place the respondent at risk and that the questions about sexuality probed confidential issues. Interviewers informed each respondent of their right to refuse to participate, and of their right to refuse to answer any question. Before starting the questionnaire, the interviewers requested verbal consent to proceed. They did not record names or other identifying feature, and took precautions that the interview was out of hearing of others.

\section{Participants}

Of the 17,377 households in 213 randomly selected enumeration areas, 20,639 adults participated from 16,707 households (96\% initial acceptance) where 85,114 people lived. $58 \%(11,872 / 20,639)$ were female; $63 \%$ $(13,017)$ were rural residents, $22.1 \%(4,563)$ urban and $14.8 \%(3,059)$ lived in the capital/metro area (Table 2$)$.

Table I: Sample weights in each country

\begin{tabular}{|c|c|c|c|c|c|c|c|c|c|}
\hline & Botswana & Lesotho & Malawi & Mozambique & Namibia & Swaziland & Zambia & Zimbabwe & TOTAL \\
\hline Sample population & 13689 & 16812 & 34488 & 9030 & 9898 & 14512 & 16189 & 12346 & 126964 \\
\hline$\%$ rural (sample population) & $45 \%$ & $83 \%$ & $85.1 \%$ & $51.6 \%$ & $58.3 \%$ & $74.5 \%$ & $65.6 \%$ & $63.6 \%$ & $70.2 \%$ \\
\hline Rural weight (Actual pop/sample pop) & 1.016 & 0.971 & 1.005 & 1.316 & 1.032 & 1.033 & 1.046 & 1.047 & 1.007 \\
\hline$\%$ urban (sample population) & $47 \%$ & $4.7 \%$ & $3.8 \%$ & $37.2 \%$ & $26.6 \%$ & $18.5 \%$ & $21.4 \%$ & $17.3 \%$ & $18.0 \%$ \\
\hline Urban weight (Actual pop/sample pop) & 0.923 & 2.034 & 1.304 & 0.693 & 0.892 & 0.909 & 0.835 & 1.003 & 1.019 \\
\hline \% capital (sample population) & $8.1 \%$ & $12.2 \%$ & $11.1 \%$ & $11.2 \%$ & $15.1 \%$ & $7 \%$ & $13.1 \%$ & $19.2 \%$ & $11.8 \%$ \\
\hline Capital weight (Actual pop/sample pop) & 1.356 & 0.799 & 0.855 & 0.564 & 1.067 & 0.890 & 1.039 & 0.840 & 0.927 \\
\hline$\%$ country (sample population) & $10.8 \%$ & $13.2 \%$ & $27.2 \%$ & $7.1 \%$ & $7.8 \%$ & $11.4 \%$ & $12.8 \%$ & $9.7 \%$ & $100 \%$ \\
\hline Country weight(Actual pop/sample pop) & 0.298 & 0.254 & 0.708 & 4.160 & 0.407 & 0.158 & 1.343 & 2.315 & 1.000 \\
\hline
\end{tabular}


Table 2: Characteristics of the sample population

\begin{tabular}{|c|c|c|c|c|c|c|c|c|c|c|}
\hline & & Botswana & Lesotho & Malawi & Mozambique & Namibia & Swaziland & Zambia & Zimbabwe & TOTAL \\
\hline Number of adults interviewed & Adults & 2526 & 2367 & 2863 & 2458 & 2649 & 1974 & 2963 & 2842 & 20639 \\
\hline \multirow{2}{*}{$\begin{array}{l}\% \text { who had not completed primary } \\
\text { school }\end{array}$} & Crude & $322 / 2367$ & $639 / 2183$ & I572/2827 & $1807 / 2425$ & $497 / 2599$ & $401 / 1827$ & $803 / 2895$ & $207 / 2772$ & $6248 / 19895$ \\
\hline & Weighted & $12 \%$ & $22 \%$ & $43 \%$ & $75 \%$ & $17 \%$ & $14 \%$ & $22 \%$ & $6 \%$ & $42 \%$ \\
\hline \multirow[t]{2}{*}{$\%$ female respondents } & Crude & $1495 / 2489$ & $1488 / 2348$ & $1683 / 2853$ & $|47| / 2446$ & $1465 / 2632$ & $1122 / 1957$ & $1605 / 2954$ & $1543 / 2827$ & $11872 / 20506$ \\
\hline & Weighted & $57 \%$ & $66 \%$ & $63 \%$ & $61 \%$ & $56 \%$ & $56 \%$ & $58 \%$ & $54 \%$ & $59 \%$ \\
\hline \multirow{2}{*}{$\begin{array}{l}\% \text { who said they did not have } \\
\text { enough food in the last week }\end{array}$} & Crude & $616 / 2216$ & $734 / 2020$ & $869 / 2180$ & $705 / 1752$ & $537 / 1799$ & $672 / 1816$ & $821 / 2175$ & $815 / 2616$ & $5769 / 16574$ \\
\hline & Weighted & $27 \%$ & $31 \%$ & $27 \%$ & $42 \%$ & $27 \%$ & $23 \%$ & $36 \%$ & $29 \%$ & $35 \%$ \\
\hline \multirow[t]{2}{*}{$\%$ with no income } & Crude & $248 / 1900$ & $419 / 1963$ & $51 / 1983$ & $66 / 1628$ & $302 / 1727$ & $230 / 1584$ & $132 / 1890$ & $155 / 2067$ & $1603 / 14742$ \\
\hline & Weighted & $11 \%$ & $17 \%$ & $2 \%$ & $4 \%$ & $14 \%$ & $8 \%$ & $5 \%$ & $6 \%$ & $5 \%$ \\
\hline Average $\mathrm{HH}$ size & Average & 4.6 & 4.7 & 4.8 & 4.9 & 5.4 & 6.2 & 3.9 & 4.7 & 5.3 \\
\hline
\end{tabular}

\section{Outcome measures}

We defined domestic physical violence by responses to the question: "In the last year, have you and your partner had violent arguments where your partner beat, kicked or slapped you?" To facilitate disclosure, interviewers asked this with the respondent alone. If this was not possible, they noted presence of a listener. Interviewers read questions without additional explanations, and recorded answers verbatim. Wherever possible, female researchers interviewed women and male researchers interviewed men. With the exception of one question about pregnancy, interviewers administered the same instrument to men and women.

We limited domestic violence to reports of physical abuse, and we had no measure of severity of the violence. We included items on attitudes to and subjective norms of domestic violence, collective efficacy to reduce domestic violence (Can your community do anything about violence against women?) and discussion of domestic violence (In the last year, how often did you talk with anyone about domestic violence? To whom did you speak most often about domestic violence?). In designing the evaluation of the impact of mass media, we anticipated that some effect might be measured in these intermediate outcomes before changing the actual occurrence of domestic physical violence.

The relevance of partner physical violence to HIV/AIDS risk came from answers to the questions "Do you think you are at risk of getting HIV?" and "If you found you were HIV positive, how would you change your sex life", considering "always use a condom" and "abstain from sex" as positive values. Negative values included "no change", "spread it intentionally", "same partner" and "sleep with virgin to cure".

\section{Analysis}

Data technicians manually digitised questionnaire data twice and eliminated keystroke errors by verifying discordant entries with the original questionnaires. We weighted final estimates in line with the national populations and the eight-country estimates weighted national indicators by the population of each country (Table 1). In a univariate analysis, we stratified each association between partner physical violence and potential risk factors by each of the others in turn (List 1, see Appendix), initially ignoring multiple influences[21,22]. We adjusted for the multiple comparisons by requiring 99\% confidence.

For risk factors not explained by any stratifying variable and those with multiple influences, a step down logistic regression model tested the effect of country, age, sex, education, income, food security, household size, occupation, and the factors in List 1 (see Appendix). The several items on attitudes to sexuality and violence showed colinearity, with no single variable attaining statistical significance in the preliminary logistic regression model. We included the variable from each group that showed the strongest association with the outcome in the model.

\section{Results}

Some $16 \%$ of men (weighted value based on 1,294/ 8,113 ) and $18 \%$ of women (weighted value based on $2,032 / 11,063)$ reported partner physical violence in the last year; $6.8 \%(809 / 11,872)$ of female respondents and $6.0 \%(521 / 8,634)$ of males declined to answer this question. The lowest rates of partner physical violence came from Mozambique (9\%) and Malawi (9\%) and the highest from Zambia (32\%) (Tables 3 and 4). The 7.1\% with someone else present at the time of the interview were more likely to report a violent altercation (OR 1.18, 95\% CI $1.02-1.35 ; 285 / 1,459$ compared with 2,974/17,381 alone at the time).

\section{Personal and household factors \\ Sex}

The gender gap in reported domestic physical was negligible in Botswana, Lesotho, Namibia, Swaziland and Zimbabwe. Elsewhere, female respondents reported being the subjects of partner physical violence more frequently than 
Table 3: MALE Experience of physical violence in the last year (beat, kicked or slapped), discussion about gender violence and participation in community action about violence against women

\begin{tabular}{|c|c|c|c|c|c|c|c|c|c|c|}
\hline & & Botswana & Lesotho & Malawi & Mozambique & Namibia & Swaziland & Zambia & Zimbabwe & TOTAL \\
\hline \multirow{3}{*}{$\begin{array}{l}\% \text { (number) who had, in the last year, had } \\
\text { violent arguments where a partner beat, } \\
\text { kicked or slapped the respondent, of those } \\
\text { who answered }\end{array}$} & Crude & $189 / 929$ & $91 / 768$ & $72 / 1109$ & $70 / 930$ & $168 / 1113$ & $162 / 1261$ & $337 / 1261$ & $205 /|23|$ & $1294 / 8113$ \\
\hline & Weighted & $21 \%$ & $12 \%$ & $6 \%$ & $8 \%$ & $15 \%$ & $21 \%$ & $27 \%$ & $17 \%$ & $16 \%$ \\
\hline & Missing & 65 & 92 & 61 & 45 & 54 & 63 & 88 & 53 & 521 \\
\hline \multirow{3}{*}{$\begin{array}{l}\% \text { who said they had not spoken with } \\
\text { anyone about gender violence in the last } \\
\text { year }\end{array}$} & Crude & $638 / 960$ & $489 / 825$ & $748 / 1167$ & $657 / 964$ & $679 / 1152$ & $515 / 798$ & $803 / 1329$ & $590 / 1271$ & $5119 / 8466$ \\
\hline & Weighted & $66 \%$ & $57 \%$ & $64 \%$ & $69 \%$ & $59 \%$ & $65 \%$ & $60 \%$ & $46 \%$ & $60 \%$ \\
\hline & Missing & 34 & 35 & 3 & 11 & 15 & 37 & 20 & 13 & 168 \\
\hline \multirow{3}{*}{$\begin{array}{l}\% \text { who had participated in community } \\
\text { activities in the last year }\end{array}$} & Crude & $71 / 930$ & $47 / 785$ & $44 / 1159$ & $64 / 964$ & $64 / 1142$ & $29 / 772$ & $48 / 1328$ & $118 / 1242$ & $485 / 8322$ \\
\hline & Weighted & $8 \%$ & $6 \%$ & $4 \%$ & $6 \%$ & $6 \%$ & $4 \%$ & $4 \%$ & $9 \%$ & $6 \%$ \\
\hline & Missing & 64 & 75 & 11 & 11 & 25 & 63 & 21 & 42 & 312 \\
\hline \multirow{3}{*}{$\begin{array}{l}\% \text { (number) who consider violence against } \\
\text { women a serious problem in their } \\
\text { community }\end{array}$} & Crude & $758 / 928$ & $796 / 1152$ & $796 / 1152$ & $613 / 952$ & $791 / 1134$ & $505 / 773$ & $722 / 1298$ & $580 / / 220$ & $5242 / 8257$ \\
\hline & Weighted & $82 \%$ & $60 \%$ & $69 \%$ & $64 \%$ & $70 \%$ & $65 \%$ & $56 \%$ & $47 \%$ & $64 \%$ \\
\hline & Missing & 66 & 60 & 18 & 23 & 33 & 62 & 51 & 64 & 377 \\
\hline \multirow{3}{*}{$\begin{array}{l}\% \text { (number) who said their community } \\
\text { CAN do anything about violence against } \\
\text { women }\end{array}$} & Crude & $692 / 899$ & $479 / 767$ & $663 / 1150$ & $508 / 903$ & $626 / 1108$ & $434 / 732$ & $545 / 1255$ & $582 / 1014$ & $4529 / 7828$ \\
\hline & Weighted & $77 \%$ & $64 \%$ & $58 \%$ & $56 \%$ & $56 \%$ & $59 \%$ & $43 \%$ & $57 \%$ & $58 \%$ \\
\hline & Missing & 95 & 93 & 20 & 72 & 59 & 103 & 94 & 270 & 806 \\
\hline
\end{tabular}

did male respondents: in Malawi, the population weighted rates were $7 \%$ and $11 \%$ for males and females respectively (based on $72 / 1,109$ and 176/1,586); in Mozambique, $7 \%$ and $11 \%$ respectively (based on $70 / 930$ and $148 / 1,374$ ) and in Zambia, 27\% and 36\% (based on $337 / 1,261$ and 538/1,509).

\section{Age}

Respondents aged 30-39 years reported violent altercations more commonly (20.4\% unweighted, based on $908 / 4,478$ ), with lower rates among older and younger respondents $(16-19$ years $11.4 \% 365 / 3,211 ; 20-29$ years $19.3 \% 1,518 / 7,931 ; 40-49$ years, $17.3 \% 376 / 2,196$; $50-$ 59 years $12.1 \% 135 / 1,118$; and $60-66$ years, $11.0 \% 26 /$ 235).

\section{Home language}

We found high reported rates of domestic physical violence in four of 29 interview languages. No less than 54\% (82/152) of Lozi speakers (Zambia) reported partner physical violence in the last year. From the same country, $46 \%$ (99/197) of Tonga, 34\% (339/995) of Bemba and $28 \%$ (206/744) Nyanja responders reported partner physical violence.

\section{Education}

Some $31 \%(6,248 / 19,895)$ of the respondents had completed primary school; $3.5 \%(744 / 20,639)$ declined to answer this question. At first glance, the average person who had not completed primary school seemed more likely to report partner physical violence: OR $1.1899 \% \mathrm{CI}$ 1.05-1.32 (2,350/12,016 among those who had not completed primary education compared with $931 / 5,933$ who had done so reported a violent altercation with a partner). This effect disappears entirely when stratifying by country; the levels of education combined with quite different rates of violent altercation seem to confound the measurement. In Zambia, the only country where education was associated with violent altercations, the average person who had not completed primary school was less likely to report a violent argument with a partner: argument with a partner: OR 0.82 95\%CI 0.69-0.98 (600/ $1,979)$ among those who had not completed primary education compared with 266/768 who had done so reported a violent altercation with a partner).

\section{Household size}

We could find no obvious trend of violent altercation with increasing household size; missing data $6.6 \%(1,360 /$ $20,639)$. The average person living in a household with more than five members was less likely to report a violent altercation than one living in a household of 1-5 people (OR 0.88 99\%CI $0.63-0.98 ; 1,295 / 7,887$ in higher occupancy households compared with 2,049/11,383 in lower occupancy households reported a violent altercation).

\section{Urban/rural residence}

Most respondents lived in rural areas $(63.1 \%$ or $13,017 /$ $20,639)$; a further $22.1 \%$ were urban $(4,563 / 20,639)$ and $14.8 \%$ lived in the capital city $(3,059 / 20,639)$. There was 
Table 4: FEMALE Experience of physical violence in the last year (beat, kicked or slapped), discussion about gender violence and participation in community action about violence against women

\begin{tabular}{|c|c|c|c|c|c|c|c|c|c|c|}
\hline & & Botswana & Lesotho & Malawi & Mozambique & Namibia & Swaziland & Zambia & Zimbabwe & TOTAL \\
\hline \multirow{3}{*}{$\begin{array}{l}\% \text { (number) who had, in the last year, } \\
\text { had violent arguments where a partner } \\
\text { beat, kicked or slapped the } \\
\text { respondent, of those who answered }\end{array}$} & Crude & $257 / 1371$ & $207 / 1309$ & $176 / 1586$ & $148 / 1374$ & $233 / 1382$ & $221 / 1034$ & $538 / 1509$ & $252 / 1498$ & $2032 / 11063$ \\
\hline & Weighted & $19 \%$ & $16 \%$ & $11 \%$ & $11 \%$ & $17 \%$ & $21 \%$ & $36 \%$ & $17 \%$ & $19 \%$ \\
\hline & Missing & 124 & 179 & 97 & 97 & 83 & 88 & 96 & 45 & 809 \\
\hline \multirow{3}{*}{$\begin{array}{l}\% \text { who said they had not spoken with } \\
\text { anyone about gender violence in the } \\
\text { last year }\end{array}$} & Crude & $1011 / 1424$ & $741 / 1433$ & $|203 /| 67 \mid$ & $1009 / 1458$ & $795 / / 452$ & $648 / 1076$ & $948 / 1586$ & $722 / 1523$ & $7077 / 11623$ \\
\hline & Weighted & $71 \%$ & $52 \%$ & $72 \%$ & $70 \%$ & $55 \%$ & $60 \%$ & $60 \%$ & $48 \%$ & $61 \%$ \\
\hline & Missing & 71 & 55 & 12 & 13 & 13 & 46 & 19 & 20 & 249 \\
\hline \multirow{3}{*}{$\begin{array}{l}\% \text { who had participated in community } \\
\text { activities in the last year }\end{array}$} & Crude & $99 / 1401$ & $53 / 1388$ & $29 / 1659$ & $76 /|45|$ & $67 / 1425$ & $29 / 1051$ & $4 I / / 576$ & $142 / 1507$ & $536 / 1 / 458$ \\
\hline & Weighted & $7 \%$ & $4 \%$ & $2 \%$ & $5 \%$ & $5 \%$ & $3 \%$ & $3 \%$ & $9 \%$ & $5 \%$ \\
\hline & Missing & 94 & 100 & 24 & 20 & 40 & 71 & 29 & 36 & 414 \\
\hline \multirow{3}{*}{$\begin{array}{l}\% \text { (number) who consider violence } \\
\text { against women a serious problem in } \\
\text { their community }\end{array}$} & Crude & $1110 / 1364$ & $856 / 1393$ & $1164 / 1659$ & $872 / \mid 421$ & $1034 / 1420$ & $699 / 1027$ & $934 / 1523$ & $777 / 1451$ & $7446 / 11257$ \\
\hline & Weighted & $81 \%$ & $62 \%$ & $70 \%$ & $59 \%$ & $73 \%$ & $68 \%$ & $61 \%$ & $53 \%$ & $66 \%$ \\
\hline & Missing & $|3|$ & 95 & 24 & 51 & 45 & 95 & 82 & 92 & 615 \\
\hline \multirow{3}{*}{$\begin{array}{l}\% \text { (number) who said their community } \\
\text { CAN do anything about violence } \\
\text { against women }\end{array}$} & Crude & $1002 / 1339$ & $479 / 767$ & $663 / 1150$ & $508 / 903$ & $626 / 1108$ & $434 / 732$ & $545 / 1255$ & $582 / 1014$ & $4529 / 7828$ \\
\hline & Weighted & $75 \%$ & $63 \%$ & $45 \%$ & $50 \%$ & $58 \%$ & $55 \%$ & $45 \%$ & $52 \%$ & $55 \%$ \\
\hline & Missing & 156 & 172 & 34 & 123 & 59 & 182 & 136 & 325 & 1187 \\
\hline
\end{tabular}

very little difference in partner physical violence: rural $17.8 \%(2,164 / 12,160)$, urban $17.2 \%(736 / 4,287)$ and capital $15.8 \%(447 / 2,837)$.

\section{Total household income}

One in every ten $(1,940 / 18,370)$ reported no income in the last month ( $11 \%$ or $2,269 / 22,630$ declined to answer this question). Stratifying by country, there was no convincing association of domestic physical violence with income (OR adjusted 1.08, 99\%CI 0.85-1.53; 346/1,757 of those with no income and 27,017/15,458 of those with an income). There was no detectable gender difference in this effect.

\section{Remunerated occupation}

One in every ten did not register an occupation $(3.7 \%$ $751 / 20,639$ missing data). Housewives were most likely to report partner physical violence (25.6\% based on 443 / $1,730)$, followed by those who described themselves as unemployed $(19.5 \%$ based on $812 / 4,169)$. There was also no convincing association between remunerated occupation and partner physical violence (OR 0.95, $99 \% \mathrm{CI} 0.8-1.1)$. We constructed a new variable to reflect the "income gap" between personal employment and total household income: overall, unemployed individuals in households with some income were more likely to report domestic physical violence (OR 1.43 99\%CI 1.27$1.60 ; 901 / 4,111$ with the income gap and 2,091/12,722 without it reported physical violence). On stratification by sex of respondent and country, however, it turned out that this association is ascribed mostly to women in Namibia and Zambia.

\section{Food security}

One in every three respondents reported having insufficient food in the last week (34.5\% unweighted, 7,070/ $20,475) ; 0.8 \%(164 / 20,639)$ declined to respond. As with personal income, the average person reporting insufficient food was slightly more likely to report partner physical violence (OR 1.22 99\%CI 1.10-1.35; 1,271/2,679 with insufficient food reported, compared with 2,052/ 12,536 with sufficient food). We could not explain this effect by urban/rural residence, country, attitudes to sexuality or sexual violence or any the personal factors we documented.

\section{Attitudes about sexuality and sexual violence}

Tables 5, 6, 7, 8, 9, 10 show the variation from country to country in attitudes about sexuality and sexual violence. Several of these beliefs were associated with partner physical violence (Tables 11 and 12): the belief that men have the right to have sex with girlfriends if they buy them presents (OR 1.42 99\%CI 1.25-1.60), it is okay for an older man to have sex with teenagers (OR1.38 99\%CI 1.20-1.59), women do not have the right to refuse sex with husbands and boyfriends (OR1.18 99\%CI 1.051.30 ) and a person has to have sex to show love (OR 1.44 99\%CI 1.38-1.59). Beliefs about gender violence were also associated with violent altercations: forcing one's partner to have sex is not rape (OR 1.23 99\%CI 1.10- 
1.37) and women sometimes deserve to be beaten (OR1.56 99\%CI 1.4-1.72). These associations were not explained by country, education, sex, remunerated occupation, income, multiple partners, household factors (like crowding, language, food security), or other attitudes and beliefs about sexuality or sexual violence.

\section{Multiple partners}

One in every four respondents $(4,468 / 17,948)$ who answered the question reported having two or more sexual partners in the last year; $15.9 \%(3,276 / 20,639)$ declined to answer. The proportion reporting multiple partners, out of those who had partners in the last year, varied somewhat by country: Botswana 32.1\% (566/ $1,760)$, Lesotho 43.9\% (780/1,760), Malawi $12.5 \%$ (274/2,195), Mozambique 31.6\% (706/2,212), Namibia $21.0 \%$ (440/2,062), Swaziland 35.1\% (517/1,465), Zambia $26.0 \%(600 / 2,316)$ and Zimbabwe $26.8 \%$ (585/ $2,175)$.

Using two or more partners in the last 12 months as a definition of multiple partners, there was a strong association with partner physical violence: female respondents OR $1.8799 \%$ CI $1.46-2.41$ (450/1564 of those with two or more partners compared with 1479/8332 among those with one on no partners) and male respondents OR 2.00 $99 \%$ CI 1.47-2.66 (627/2755 among those with two or more partners compared with 592/4616 among those with one or no partners).

In all age groups in all countries, having multiple partners was a risk factor for violent altercations. A logistic model taking into account country, food security, sex of respondent, income, education and employment accentuated the risk of violent altercations for people with multiple partners (unadjusted OR 1.75, adjusted OR 2.03 99\%CI 1.65-
2.42, indicating underestimation of the unadjusted estimate).

Partner physical violence increased progressively with number of partners in the last 12 months: 234/1689 $(13.9 \%)$ with no partners, $16.3 \%$ (1849/11324) with one partner, $22.7 \%(516 / 2269)$ with two partners, $25.4 \%$ (253/1034) with three partners, 29.2\% (118/405) with four and $29.2 \%(185 / 633)$ with five or more partners reported domestic physical violence in the last year $\left(\chi^{2}\right.$ $199.8,5 \mathrm{df})$.

\section{Community dynamics and collective efficacy}

A large proportion of the sample (65\%, 12760/19626) said that domestic violence was considered a serious issue in their community (4.9\% missing data, 1004/20639). Yet two thirds $(9944 / 15880)$ of those who did not report physical violence and one half of those reporting partner physical violence in the last year (1654/3336) had never spoken about it. Those who spoke about it did so most frequently with friends (50.0\% 3754/7504) and family $(24.2 \%, 1819 / 7504)$. One in every ten said they had discussed with a neighbour (720/7504) and another one in ten with a partner or spouse $(745 / 7504)$. There were no remarkable differences between male and female respondents, or between those who reported violent altercations and those who had not done so.

Over one half of the respondents said that their community could do something about violence against women (unweighted 56.2\% based on 10466/18617, missing data $2017 / 20639$ or $9.7 \%$ ). Male respondents were more likely to express collective efficacy (OR 1.12 99\%CI 1.02-1.23, $4529 / 7828$ male and 5879/10685 female respondents felt their communities could do something about violence against women). Collective efficacy was highest in Bot-

Table 5: Male attitudes about sex

\begin{tabular}{|c|c|c|c|c|c|c|c|c|c|c|}
\hline & & Botswana & Lesotho & Malawi & Mozambique & Namibia & Swaziland & Zambia & Zimbabwe & TOTAL \\
\hline \multirow{3}{*}{$\begin{array}{l}\% \text { (number) who said women do not have } \\
\text { the right to refuse to have sex with their } \\
\text { husbands or boyfriends. }\end{array}$} & Crude & $383 / 981$ & $393 / 829$ & $568 / 1165$ & $538 / 970$ & $436 / I I 5 I$ & $369 / 824$ & $681 / 1255$ & $614 / 1258$ & $3982 / 8433$ \\
\hline & Weighted & $39 \%$ & $47 \%$ & $49 \%$ & $55 \%$ & $38 \%$ & $45 \%$ & $54 \%$ & $49 \%$ & $47 \%$ \\
\hline & Missing & 13 & 31 & 5 & 5 & 16 & 11 & 94 & 26 & 201 \\
\hline \multirow{3}{*}{$\begin{array}{l}\text { \% (number) who said a person has to have } \\
\text { sex with their boyfriend or girlfriend to } \\
\text { show that they love them }\end{array}$} & Crude & $350 / 983$ & $528 / 838$ & $505 / 1166$ & $523 / 971$ & $446 / 1152$ & $407 / 821$ & $596 / 1336$ & $318 / 1277$ & $3673 / 8544$ \\
\hline & Weighted & $36 \%$ & $62 \%$ & $44 \%$ & $57 \%$ & $39 \%$ & $50 \%$ & $45 \%$ & $25 \%$ & $44 \%$ \\
\hline & Missing & 11 & 22 & 4 & 5 & 15 & 14 & 13 & 7 & 90 \\
\hline \multirow{3}{*}{$\begin{array}{l}\% \text { (number) who said it is okay for an older } \\
\text { man to have sex with teenagers. }\end{array}$} & Crude & $75 / 985$ & $162 / 820$ & $62 / 1168$ & $196 / 972$ & III/II58 & $84 / 826$ & $129 / 1343$ & $105 / 1280$ & $924 / 8552$ \\
\hline & Weighted & $8 \%$ & $21 \%$ & $5 \%$ & $21 \%$ & $10 \%$ & $10 \%$ & $10 \%$ & $8 \%$ & $11 \%$ \\
\hline & Missing & 9 & 40 & 2 & 3 & 9 & 9 & 6 & 4 & 82 \\
\hline \multirow{3}{*}{$\begin{array}{l}\% \text { (number) who said men have the right to } \\
\text { have sex with their girlfriends if they buy } \\
\text { them gifts }\end{array}$} & Crude & $172 / 980$ & $331 / 822$ & $285 / 1166$ & $491 / 969$ & $365 / 1154$ & $189 / 827$ & $509 / 1342$ & $266 / 1280$ & $2608 / 8540$ \\
\hline & Weighted & $18 \%$ & $39 \%$ & $25 \%$ & $53 \%$ & $32 \%$ & $23 \%$ & $38 \%$ & $21 \%$ & $31 \%$ \\
\hline & Missing & 14 & 38 & 4 & 6 & 13 & 8 & 7 & 4 & 94 \\
\hline
\end{tabular}


Table 6: Female attitudes about sex

\begin{tabular}{|c|c|c|c|c|c|c|c|c|c|c|}
\hline & & Botswana & Lesotho & Malawi & Mozambique & Namibia & Swaziland & Zambia & Zimbabwe & TOTAL \\
\hline \multirow{3}{*}{$\begin{array}{l}\% \text { (number) who said women do not have } \\
\text { the right to refuse to have sex with their } \\
\text { husbands or boyfriends. }\end{array}$} & Crude & $480 / 1466$ & $594 / 1447$ & $812 / 1679$ & $772 / 1458$ & $448 / 1457$ & $429 / 1099$ & $856 / 1516$ & $662 / 1513$ & $5053 / 11635$ \\
\hline & Weighted & $32 \%$ & $40 \%$ & $49 \%$ & $52 \%$ & $31 \%$ & $39 \%$ & $57 \%$ & $44 \%$ & $43 \%$ \\
\hline & Missing & 29 & $4 I$ & 4 & 13 & 8 & 23 & 89 & 30 & 237 \\
\hline \multirow{3}{*}{$\begin{array}{l}\% \text { (number) who said a person has to have } \\
\text { sex with their boyfriend or girlfriend to } \\
\text { show that they love them }\end{array}$} & Crude & $428 / 1464$ & $843 / / 452$ & $763 / 1671$ & $743 /|46|$ & $411 / 1458$ & $449 / 1104$ & $651 / 1590$ & $266 / 1533$ & $4554 / 11733$ \\
\hline & Weighted & $29 \%$ & $58 \%$ & $46 \%$ & $54 \%$ & $28 \%$ & $41 \%$ & $42 \%$ & $17 \%$ & $39 \%$ \\
\hline & Missing & 31 & 36 & 12 & 10 & 7 & 18 & 15 & 10 & 139 \\
\hline \multirow{3}{*}{$\begin{array}{l}\% \text { (number) who said it is okay for an } \\
\text { older man to have sex with teenagers. }\end{array}$} & Crude & $79 / 1470$ & $226 / 1433$ & $104 / 1679$ & $289 / 1461$ & $97 / 1459$ & $108 / 1112$ & $126 / 1596$ & $134 / 1539$ & $1163 / 11749$ \\
\hline & Weighted & $5 \%$ & $16 \%$ & $6 \%$ & $20 \%$ & $7 \%$ & $10 \%$ & $8 \%$ & $9 \%$ & $10 \%$ \\
\hline & Missing & 25 & 55 & 4 & 10 & 6 & 10 & 9 & 4 & 123 \\
\hline \multirow{3}{*}{$\begin{array}{l}\% \text { (number) who said men have the right } \\
\text { to have sex with their girlfriends if they } \\
\text { buy them gifts }\end{array}$} & Crude & $236 / 1468$ & $534 / / 426$ & $467 / 167 \mid$ & $651 / 1462$ & $286 / 1450$ & $186 / 1105$ & $513 / 1593$ & $216 / 1531$ & $3089 / 11706$ \\
\hline & Weighted & $16 \%$ & $37 \%$ & $28 \%$ & $48 \%$ & $20 \%$ & $17 \%$ & $33 \%$ & $14 \%$ & $27 \%$ \\
\hline & Missing & 27 & 62 & 12 & 9 & 15 & 17 & 12 & 12 & 166 \\
\hline
\end{tabular}

swana (75.6\% 1715/2268) and Lesotho (62\%, 1299/ 2095) and lowest in Zambia (44.5\%, 1215/2732).

\section{Relevance of partner physical violence to HIV risk}

People who reported partner physical violence (male or female) were significantly more likely to believe they were at risk of getting HIV (OR 1.51, 99\%CI 1.37-1.68; 1615/ 3075 who reported partner physical violence and 6261/ 14832 who did not report partner physical violence said they were at risk of HIV infection). This was not explained by country, sex of the respondent or any of the factors we could test in this study.

The average male respondent who reported partner physical violence was significantly more likely to anticipate a negative reaction to knowing he was HIV positive (no change, spread intentionally, sleep with virgin, etc) compared with one who had not suffered violence in the last year (OR 1.51, 99\%CI 1.23-1.83, 286/1163 among those reporting and 1089/6142 not reporting partner physical violence). This association did not hold for female respondents, and among men it was not explained by country or any of the other variables we could test (List 1, see appendix).

\section{Discussion}

High rates of domestic physical violence in all eight countries were conspicuously independent of education, household size, household income and remunerated employment. After taking into account age, sex, country and other factors, domestic physical violence was strongly associated with income gradients (being unemployed in

Table 7: Male attitudes about violence

\begin{tabular}{|c|c|c|c|c|c|c|c|c|c|c|}
\hline & & Botswana & Lesotho & Malawi & Mozambique & Namibia & Swaziland & Zambia & Zimbabwe & TOTAL \\
\hline \multirow{3}{*}{$\begin{array}{l}\% \text { (number) who said women sometimes } \\
\text { deserve to be beaten }\end{array}$} & Crude & $357 / 978$ & $345 / 818$ & $348 / 1166$ & $395 / 968$ & $505 / 1159$ & $415 / 822$ & $715 / 1337$ & $421 / 1278$ & $3501 / 8526$ \\
\hline & Weighted & $37 \%$ & $41 \%$ & $30 \%$ & $41 \%$ & $44 \%$ & $51 \%$ & $53 \%$ & $33 \%$ & $41 \%$ \\
\hline & Missing & 16 & 42 & 4 & 7 & 8 & 13 & 12 & 6 & 108 \\
\hline \multirow{3}{*}{$\begin{array}{l}\% \text { (number) who said if a woman gets raped } \\
\text { its her own fault }\end{array}$} & Crude & $165 / 98 \mid$ & $260 / 823$ & $508 / 1162$ & $452 / 970$ & $209 / 1155$ & $161 / 816$ & $268 / 1337$ & $178 / 1272$ & $2201 / 8516$ \\
\hline & Weighted & $17 \%$ & $31 \%$ & $44 \%$ & $49 \%$ & $18 \%$ & $20 \%$ & $20 \%$ & $14 \%$ & $26 \%$ \\
\hline & Missing & 13 & 37 & 8 & 5 & 12 & 19 & 12 & 12 & 118 \\
\hline \multirow{3}{*}{$\begin{array}{l}\% \text { (number) who said forcing sex with } \\
\text { someone you know is not rape }\end{array}$} & Crude & $242 / 982$ & $302 / 824$ & $299 / 1165$ & $240 / 971$ & $254 / 1158$ & $84 / 821$ & $346 / 1338$ & $205 / I 28 I$ & $1972 / 8540$ \\
\hline & Weighted & $25 \%$ & $36 \%$ & $26 \%$ & $25 \%$ & $22 \%$ & $10 \%$ & $26 \%$ & $16 \%$ & $23 \%$ \\
\hline & Missing & 12 & 36 & 5 & 4 & 9 & 14 & 11 & 3 & 94 \\
\hline \multirow{3}{*}{$\begin{array}{l}\% \text { (number) who said Forcing your partner } \\
\text { to have sex, is NOT rape }\end{array}$} & Crude & 198/982 & $292 / 829$ & $455 / 1166$ & $309 / 971$ & $401 / 1157$ & $26 \mid / 821$ & $618 / 1340$ & $395 / 1276$ & $2929 / 8542$ \\
\hline & Weighted & $20 \%$ & $35 \%$ & $39 \%$ & $33 \%$ & $35 \%$ & $32 \%$ & $46 \%$ & $31 \%$ & $34 \%$ \\
\hline & Missing & 12 & 31 & 4 & 4 & 10 & 14 & 9 & 8 & 92 \\
\hline \multirow{3}{*}{$\begin{array}{l}\% \text { (number) who said violence between a } \\
\text { man and a woman is a private matter in } \\
\text { which others shouldn't interfere }\end{array}$} & Crude & $296 / 977$ & $522 / 823$ & $875 / 1165$ & $546 / 970$ & $497 / 1152$ & $430 / 820$ & $754 / 1335$ & $628 / 1272$ & $4548 / 8514$ \\
\hline & Weighted & $30 \%$ & $63 \%$ & $75 \%$ & $58 \%$ & $43 \%$ & $53 \%$ & $57 \%$ & $50 \%$ & $54 \%$ \\
\hline & Missing & 17 & 37 & 5 & 5 & 15 & 15 & 14 & 12 & 120 \\
\hline
\end{tabular}


Table 8: Male attitudes about violence

\begin{tabular}{|c|c|c|c|c|c|c|c|c|c|c|}
\hline & & Botswana & Lesotho & Malawi & Mozambique & Namibia & Swaziland & Zambia & Zimbabwe & TOTAL \\
\hline \multirow{3}{*}{$\begin{array}{l}\% \text { (number) who said women sometimes } \\
\text { deserve to be beaten }\end{array}$} & Crude & $279 / 1459$ & $426 / 1429$ & $654 / 1677$ & $539 / 1463$ & $425 / 1454$ & $436 / 1099$ & $751 / 1592$ & $368 / 1536$ & $3878 / 11709$ \\
\hline & Weighted & $19 \%$ & $30 \%$ & $39 \%$ & $38 \%$ & $29 \%$ & $40 \%$ & $47 \%$ & $24 \%$ & $33 \%$ \\
\hline & Missing & 36 & 59 & 6 & 8 & 11 & 23 & 13 & 7 & 163 \\
\hline \multirow{3}{*}{$\begin{array}{l}\% \text { (number) who said if a woman gets } \\
\text { raped its her own fault }\end{array}$} & Crude & $158 / 1463$ & $339 / 1427$ & $625 / 1673$ & $544 / 1462$ & $143 / \mid 458$ & $120 / 1104$ & $306 / 1591$ & $17 \mid / 1538$ & $2406 / 11716$ \\
\hline & Weighted & $11 \%$ & $24 \%$ & $37 \%$ & $39 \%$ & $10 \%$ & $11 \%$ & $19 \%$ & $11 \%$ & $21 \%$ \\
\hline & Missing & 32 & 61 & 10 & 9 & 7 & 18 & 14 & 5 & 156 \\
\hline \multirow{3}{*}{$\begin{array}{l}\% \text { (number) who said forcing sex with } \\
\text { someone you know is not rape }\end{array}$} & Crude & $324 / 1466$ & $506 / 1428$ & $437 / 1674$ & $436 / 1462$ & $259 / 1459$ & $146 / \mid 108$ & $448 / 1593$ & $261 / / 535$ & $2817 / 11725$ \\
\hline & Weighted & $22 \%$ & $36 \%$ & $26 \%$ & $29 \%$ & $18 \%$ & $13 \%$ & $28 \%$ & $17 \%$ & $24 \%$ \\
\hline & Missing & 29 & 60 & 9 & 9 & 6 & 14 & 12 & 8 & 147 \\
\hline \multirow{3}{*}{$\begin{array}{l}\% \text { (number) who said Forcing your } \\
\text { partner to have sex, is NOT rape }\end{array}$} & Crude & $279 / 1467$ & $509 / 1458$ & $754 / 1676$ & $536 / 1464$ & $476 / / 457$ & $371 / 1110$ & $807 / 1592$ & $515 / 1529$ & $4247 / 11753$ \\
\hline & Weighted & $19 \%$ & $35 \%$ & $45 \%$ & $36 \%$ & $33 \%$ & $34 \%$ & $51 \%$ & $34 \%$ & $36 \%$ \\
\hline & Missing & 28 & 30 & 7 & 7 & 8 & 12 & 13 & 14 & 119 \\
\hline \multirow{3}{*}{$\begin{array}{l}\% \text { (number) who said violence between a } \\
\text { man and a woman is a private matter in } \\
\text { which others shouldn't interfere }\end{array}$} & Crude & $360 / 1458$ & $809 / 1428$ & $1335 / 1678$ & $8|3 /| 46 \mid$ & $556 / 1457$ & $517 / 1102$ & $831 / 1591$ & $790 / 1523$ & $6011 / 11698$ \\
\hline & Weighted & $24 \%$ & $57 \%$ & $80 \%$ & $56 \%$ & $38 \%$ & $47 \%$ & $52 \%$ & $52 \%$ & $51 \%$ \\
\hline & Missing & 37 & 60 & 5 & 10 & 8 & 20 & 14 & 20 & 174 \\
\hline
\end{tabular}

the context of some household income) and home language in one country, and with multiple partners in the last year in all countries. Victims of partner physical violence were more likely to feel at risk of HIV infection and more likely to anticipate antisocial behaviour if they found they were HIV positive.

This is a cross-sectional household survey based on faceto-face interviews. This design limits conclusions about causality of, for example, multiple partners leading to physical violence or being the consequence of physical violence. It is likely that some respondents held back from expressing their true belief or experience. Even with the best field practices - including independent translation and back-translation of questionnaires, standardised training of local interviewers, in-country piloting and consultation with local community representatives, doubledata entry and verification - measurement error is possible. The sample makes the results relevant to the eight countries, but not necessarily to other countries.
A major limitation is that we only considered domestic physical violence. This almost certainly underestimates the level of domestic violence. Other forms (verbal, sexual, economic and psychological) were beyond the scope of the study. In all countries we asked the same questions of men and women. We were able to examine several intermediate outcomes related to domestic violence - including attitudes, subjective norms, collective efficacy and discussion/socialisation - but most of these could be addressed only superficially through one or two items in the questionnaire.

We had no measure of severity or frequency of physical domestic violence, making it difficult to interpret the proportion of men and women who reported partner violence in the last year. Large studies in the UK and USA have reported similar proportions of partner violence for males and females, but found male on female violence to be more severe than female on male violence[23,24]. It is quite possible that the same is true for southern Africa.

Table 9: Male attitudes and subjective norms about sexual violence

\begin{tabular}{|c|c|c|c|c|c|c|c|c|c|c|}
\hline$\%$ (number) who said & & Botswana & Lesotho & Malawi & Mozambique & Namibia & Swaziland & Zambia & Zimbabwe & TOTAL \\
\hline \multirow{3}{*}{$\begin{array}{l}\text { In my culture it is acceptable for a man to } \\
\text { beat his wife }\end{array}$} & Crude & $268 / 983$ & $337 / 812$ & $151 / 1163$ & $317 / 965$ & $327 / 1158$ & $203 / 813$ & $507 / 1329$ & $382 / 1275$ & $2492 / 8498$ \\
\hline & Weighted & $27 \%$ & $41 \%$ & $13 \%$ & $33 \%$ & $28 \%$ & $25 \%$ & $38 \%$ & $30 \%$ & $29 \%$ \\
\hline & Missing & 11 & 48 & 7 & 10 & 9 & 22 & 20 & 9 & 136 \\
\hline \multirow{3}{*}{$\begin{array}{l}\text { most people in our community feel women } \\
\text { have a right to refuse sex with their partners }\end{array}$} & Crude & $473 / 899$ & $386 / 766$ & $574 / 1142$ & $461 / 957$ & $741 / 1133$ & $338 / 766$ & $601 / 1251$ & $505 / 1186$ & $4079 / 8100$ \\
\hline & Weighted & $53 \%$ & $52 \%$ & $50 \%$ & $49 \%$ & $66 \%$ & $44 \%$ & $48 \%$ & $43 \%$ & $50 \%$ \\
\hline & Missing & 95 & 94 & 28 & 18 & 34 & 69 & 98 & 98 & 534 \\
\hline \multirow{3}{*}{$\begin{array}{l}\text { most people in our community feel forcing } \\
\text { your partner to have sex is rape }\end{array}$} & Crude & $650 / 943$ & $509 / 777$ & $616 / 1150$ & $582 / 956$ & $760 / 1138$ & $491 / 801$ & $602 / 1266$ & $757 / 1212$ & $4967 / 8243$ \\
\hline & Weighted & $69 \%$ & $66 \%$ & $54 \%$ & $60 \%$ & $67 \%$ & $61 \%$ & $47 \%$ & $63 \%$ & $60 \%$ \\
\hline & Missing & 51 & 83 & 20 & 19 & 29 & 34 & 83 & 72 & 391 \\
\hline
\end{tabular}


Table 10: Female attitudes and subjective norms about sexual violence

\begin{tabular}{|c|c|c|c|c|c|c|c|c|c|c|}
\hline$\%$ (number) who said & & Botswana & Lesotho & Malawi & Mozambique & Namibia & Swaziland & Zambia & Zimbabwe & TOTAL \\
\hline \multirow{3}{*}{$\begin{array}{l}\text { In my culture it is acceptable for a man to } \\
\text { beat his wife }\end{array}$} & Crude & $307 / 1449$ & $495 / 1418$ & $250 / 1674$ & $441 / 1463$ & $310 / 1451$ & $183 / 1093$ & $531 / / 587$ & $425 / 1528$ & $2942 / 11663$ \\
\hline & Weighted & $21 \%$ & $35 \%$ & $15 \%$ & $32 \%$ & $21 \%$ & $17 \%$ & $34 \%$ & $28 \%$ & $25 \%$ \\
\hline & Missing & 46 & 70 & 9 & 8 & 14 & 29 & 18 & 15 & 209 \\
\hline \multirow{3}{*}{$\begin{array}{l}\text { most people in our community feel } \\
\text { women have a right to refuse sex with } \\
\text { their partners }\end{array}$} & Crude & $683 / 1317$ & $682 / 1302$ & $721 / 1647$ & $675 / 1421$ & $933 / 1423$ & $528 / 1041$ & $685 / 1444$ & $685 / 1381$ & $5592 / 10976$ \\
\hline & Weighted & $52 \%$ & $54 \%$ & $44 \%$ & $49 \%$ & $66 \%$ & $50 \%$ & $47 \%$ & $50 \%$ & $51 \%$ \\
\hline & Missing & 178 & 186 & 36 & 50 & 42 & 81 & 161 & 162 & 896 \\
\hline \multirow{3}{*}{$\begin{array}{l}\text { most people in our community feel } \\
\text { forcing your partner to have sex is rape }\end{array}$} & Crude & $912 / 1390$ & $916 / 1351$ & $793 / 1641$ & $762 / 1423$ & $926 / 1424$ & $664 / 1064$ & $673 / 1477$ & $909 / 1440$ & $6555 / 11210$ \\
\hline & Weighted & $66 \%$ & $69 \%$ & $48 \%$ & $54 \%$ & $65 \%$ & $62 \%$ & $45 \%$ & $63 \%$ & $59 \%$ \\
\hline & Missing & 105 & 137 & 42 & 48 & 41 & 58 & 128 & 103 & 662 \\
\hline
\end{tabular}

The men we interviewed were at home during working hours and, in this respect at least, they may not be typical of all men in the eight countries. We also did not ask who initiated the altercation, so it is also possible these reports reflect women defending themselves from male-initiated violence. Even so, the finding is compatible with a degree of female agency in domestic physical violence and supports our conclusions from South Africa that initiatives against sexual violence should look beyond gender stereotypes of victims and villains[25].

There was no recognisable pattern of poverty and domestic violence between countries (Mozambique, the poorest country, reported the lowest rates while Zambia reported the highest). We also did not find significant associations between victims and their individual education or employment, and we could only address the income gradient between partners through a proxy variable. It is possible that in-household inequality in education and income could be more relevant to domestic violence than we were able to measure in this study[26]. There was no interpretable association between the Gini coefficient (measuring inequality in the country) and male or female reports of violence (Tables 3 and 4). The Gini coefficient used for Botswana and Lesotho was 0.63, Malawi 0.50, Mozambique 0.40, Namibia 0.74, Swaziland 0.61, Zambia 0.42 and Zimbabwe 0.61[27].

The occurrence of domestic physical violence in some parts of Zambia raises the question of something being done differently there, despite efforts to reproduce exactly the same survey in all countries. Whatever the reason for the higher rates of domestic physical violence detected in Zambia, it seems unlikely the same error lies behind the inability to demonstrate an association between violent altercations and education, overcrowding, income and age - consistent across all the countries.

\section{Conclusion}

If there is good news from this study, it is that multiple partners, attitudes and subjective norms are more in the control of most individuals than are poverty, overcrowding and education - without detracting from the need for massive investment in these sectors.

An unanswered question is how to modify attitudes or multiple partners. There is also no guarantee that changing attitudes will, on its own, impact on behaviour. The study confirms the importance of moving beyond gender stereotypes of victims and villains. Men also report suffering partner physical violence, although our inability to measure severity could mask an important gender difference. The solutions to domestic violence lie with both men and women, and both have agency in this regard. There was also a prominent sense of collective efficacy, the majority expressing they could do something about domestic violence.

Although many thought their community could deal with violence against women, few victims and still fewer of the non-victims said they had discussed violence against women with anyone. Stimulating discussions about violence against women offers one direction for initiatives against partner physical violence. Wider discussion could influence social norms, in addition to targeting individual attitudes and supportive public policy.

\section{Appendix}

List 1. Variables tested sequentially, from which independent associations were included in logistic regression model

\section{Individual and household characteristics}

How many people live in the household

Age and sex of each one

Language spoken at home most of the time

Last grade of education respondent completed

Main occupation of respondent 


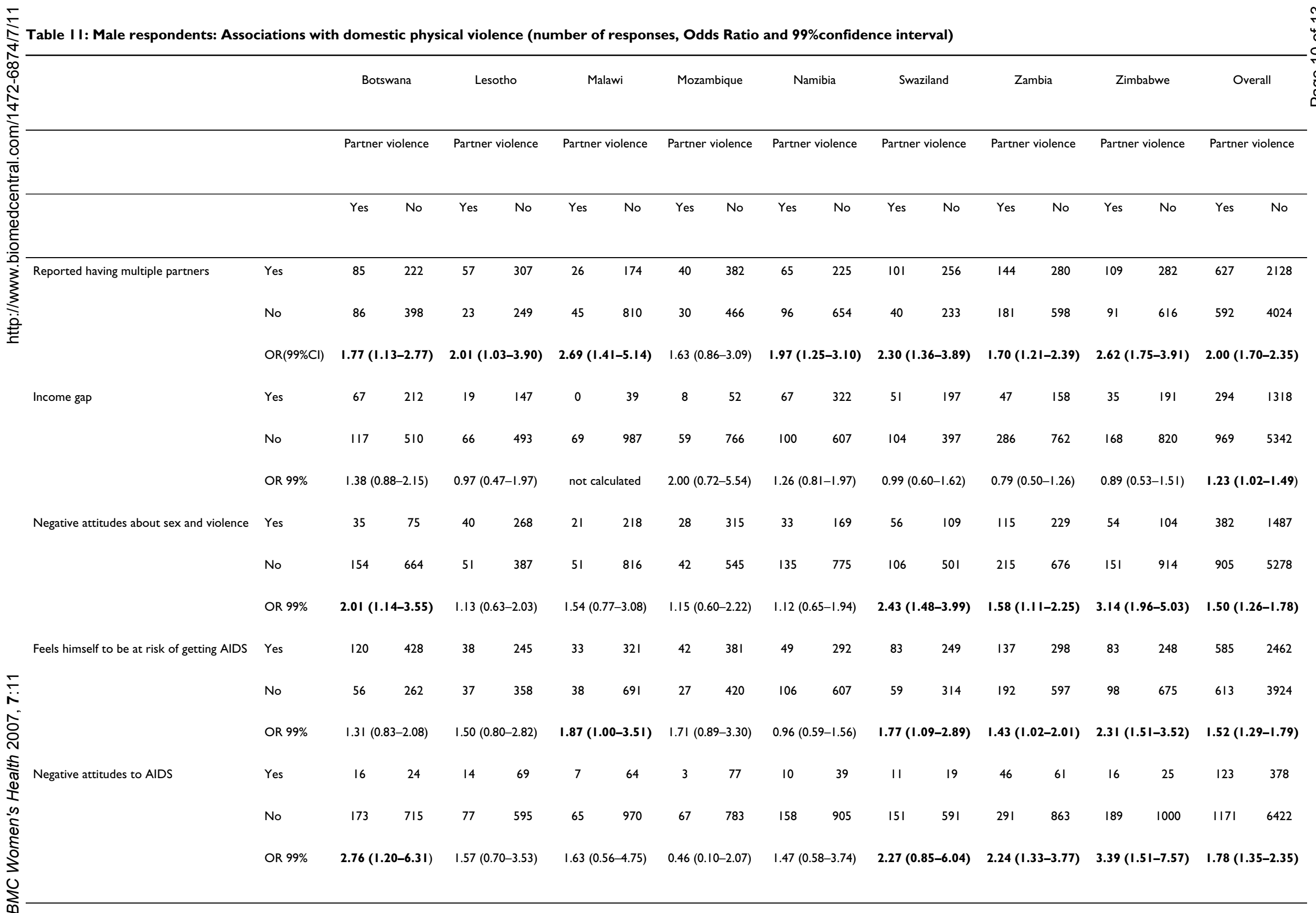


$\mp$ Table I2: Female respondents: Associations with domestic physical violence (number of responses, Odds Ratio and 99\%confidence interval)

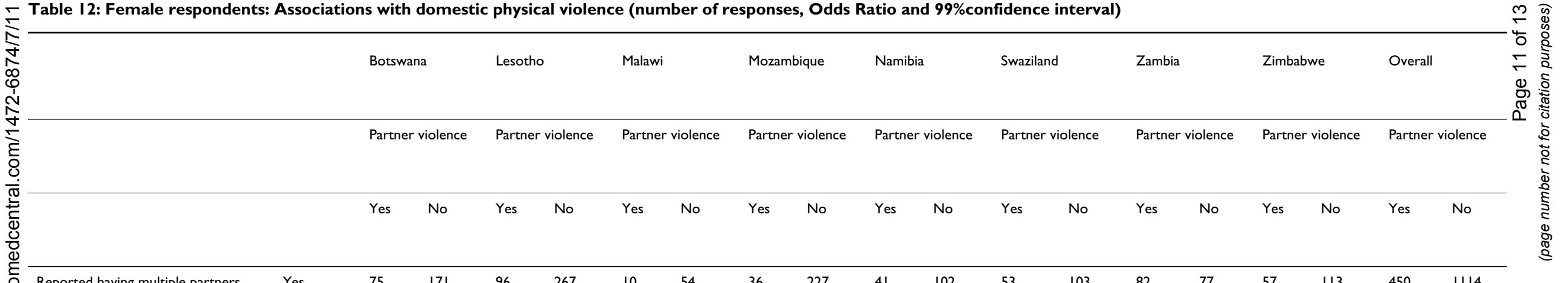

\begin{tabular}{|c|c|c|c|c|c|c|c|c|c|c|c|c|c|c|c|c|c|c|c|}
\hline Reported having multiple partners & Yes & 75 & 171 & 96 & 267 & 10 & 54 & 36 & 227 & 41 & 102 & 53 & 103 & 82 & 77 & 57 & 113 & 450 & 1114 \\
\hline
\end{tabular}

$\begin{array}{lllllllllllllllllll}\text { No } & 159 & 755 & 86 & 599 & 164 & 1278 & 111 & 979 & 189 & 993 & 139 & 518 & 447 & 798 & 184 & 933 & 1479 & 6853\end{array}$

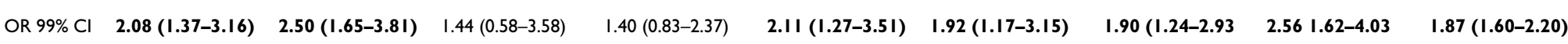

Income gap

\begin{tabular}{|c|c|c|c|c|c|c|c|c|c|c|c|c|c|c|c|c|c|c|}
\hline Yes & 123 & 558 & 110 & 502 & 4 & 58 & 19 & 171 & 129 & 524 & 114 & 382 & 357 & 575 & 98 & 516 & 954 & 3286 \\
\hline No & 128 & 538 & 91 & 564 & 171 & 1340 & 125 & 997 & 101 & 614 & 98 & 412 & 176 & 390 & 153 & 701 & 1043 & 5556 \\
\hline
\end{tabular}

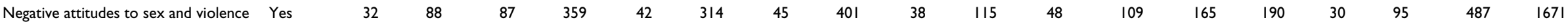

$\begin{array}{lllllllllllllllllllll}\text { No } & 224 & 1024 & 120 & 727 & 134 & 1093 & 103 & 824 & 195 & 1031 & 172 & 696 & 363 & 762 & 222 & 1147 & 1533 & 7304\end{array}$

OR $99 \% \mathrm{Cl} \quad 1.66(0.95-2.91) \quad 1.47(0.99-2.19) \quad 1.09(0.67-1.77) \quad 0.90(0.55-1.46) \quad 1.75(1.04-2.93) \quad 1.78(1.09-2.92) \quad 1.82(1.33-2.50) \quad 1.63(0.93-2.88) \quad 1.39(1.29-1.79)$

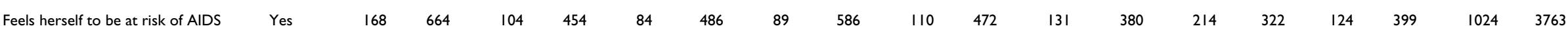

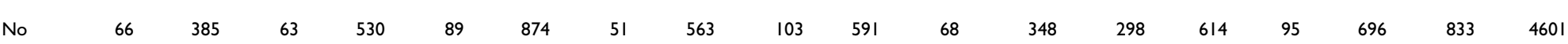

స

OR $99 \% \mathrm{Cl} \quad \mathrm{I} .48(0.98-2.22) \quad 1.93(1.24-2.99) \quad 1.70(1.12-2.57) \quad 1.68(1.04-2.69) \quad 1.34(0.91-1.97) \quad 1.76(1.15-2.70) \quad 1.37(1.02-1.83) \quad 2.28(1.56-3.33) \quad 1.50(1.32-1.72)$

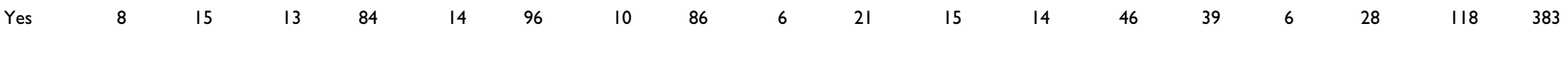

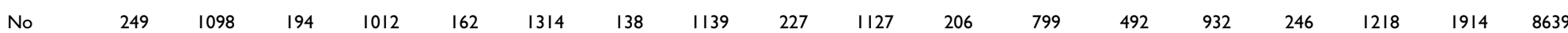

$\mathrm{OR} 99 \% \mathrm{Cl} \quad 2.35(0.77-7.14) \quad 0.81(0.37-1.78) \quad 1.18(0.55-2.55) \quad 0.96(0.39-2.34) \quad 1.42(0.43-4.72) \quad 4.16(1.68-10.30) \quad 2.23(1.27-3.94) \quad 1.06(0.33-3.43) \quad 1.39(1.05-1.84)$ 
Total household income per month

Did household have enough food in the last week

Was the respondent alone or was someone listening

\section{HIV risk}

Do you think you are at risk of getting HIV

If you found you were HIV positive, how would you change your sex life

\section{Sexual violence}

If a woman gets raped its her own fault.

Forcing sex with someone you know is not rape.

Forcing your partner to have sex is rape.

\section{Subjective norms about sexual violence}

Do most people in your community feel forcing your partner to have sex is rape?

Do most people in your community feel women have a right to refuse sex with their partners?

Is violence against women considered a serious problem in this community?

\section{Collective efficacy about sexual violence}

Can your community do anything about violence against women?

\section{Attitudes to domestic violence}

Women have the right to refuse to have sex with partner

Violence between a man and a woman is a private matter Women sometimes deserve to be beaten.

\section{Subjective norms about domestic violence}

Do most people in your community feel women sometimes deserve to be beaten?

\section{Discussion about domestic violence}

In the last year, how often did you talk with anyone about domestic violence? [never, seldom or often]

To whom did you speak most often?

\section{Practices relating to domestic violence}

What community activity about violence against women have you participated in?
In the last year, have you and your partner had violent arguments where someone was physically hurt?

\section{Transactional sex}

Men have the right to have sex with their girlfriends if they buy them gifts.

Its okay for an older man to have sex with teenagers

A person has to have sex with their boyfriend or girlfriend to show that they love them.

Do most of your friends feel men have the right to sex with their girlfriends if they buy them gifts?

\section{Competing interests}

All authors declare that there is no competing interest. Esca Scheepers and Sue Goldstein were employed by Soul City, which subcontracted the national education-entertainment programmes in the eight countries.

\section{Authors' contributions}

NA was involved in study and questionnaire design, statistical analysis, drafting manuscript. AHF was involved in statistical analysis, interpretation and drafting manuscript. SM was involved in study design, acquisition of data, drafting manuscript. ES and SG were involved in study and questionnaire design, analysis and interpretation, drafting manuscript, administration and technical support. NA, AHF, ES and SG had full access to all data and take responsibility for the integrity of the data and accuracy of data analysis. All authors read and approved the final manuscript.

\section{Acknowledgements}

The eight national surveys were funded by a grant from the European Union, made available through Soul City. Lorenzo Monasta trained fieldworkers and coordinated fieldwork in Malawi, as did Charlie Whitaker in Mozambique, Sharmila Mhatre in Zambia, Manuel Pascual Salcedo in Swaziland and Lesotho, and Serge Merhi in Namibia and Zimbabwe. Marietjie Myburg supported fieldwork in Swaziland and Lesotho. Candyce Hamel provided analysis support.

\section{References}

I. World Health Organization: World report on violence and health 2002 [http://www.who.int/violence injury prevention/violence/ world report/en/full en.pdf). Geneva : WHO (Accessed 26 July 2005)

2. Campbell JC: Health consequences of intimate partner violence. Lancet 2002, 359:1331-6.

3. Vantage: Domestic violence: Update for healthcare providers. 1998 [http://vantageproed.com/viol/viol.htm]. Retrieved 8 March 2007

4. Rodriguez MA, Bauer HM, McLoughlin E, Grumbach K: Screening and intervention for intimate partner abuse. JAMA 1999 , 282:468-474.

5. Ilika AL, Okonkwo PI, Adogu P: Intimate Partner Violence Among Women of Childbearing Age in a Primary Health Care Centre in Nigeria. Afr J Reprod Health 2002, 6:53-58. 
6. Koenig MA, Lutalo $T$, Zhao $F$, et al.: Domestic Violence in rural Uganda: Evidence from a community-based study. Bull World Health Organ 2003, 81:53-60.

7. Mbokota M, Moodley J: Domestic Abuse - An Antenatal Survey at King Edward VIII Hospital, Durban. S Afr Med J 2003, 93:455-457.

8. Jewkes R, Levin J, Penn-Kekana L: Risk Factors For Domestic Violence: Findings From A South African Cross-Sectional Study. Soc Sci Med 2002, 55:1603-1617.

9. Jewkes RK, Levin JB, Penn-Kekana LA: Gender Inequalities, Intimate Partner Violence and HIV Preventive Practices: Findings of a South African Cross-Sectional Study. Soc Sci Med 2003, 56(I): 125-134.

10. Jewkes R: Intimate partner violence: causes and prevention. Lancet 2002, 359:

II. Greig FE, Koopman C: Multilevel analysis of women's empowerment and HIV prevention: quantitative survey results from a preliminary study in Botswana. AIDS Behav 2003 7(2): 195-208.

12. Mills JE, Anarfi JK: HIV Risk Environment for Ghanaian Women: Challenges to Prevention. Social Science and Medicine 2002, 54:325-337.

13. Mtika MM: The AIDS Epidemic in Malawi and Its Threat to Household Food Security. Human Organization 200I, 60(2): $178-188$.

14. Leclerc-Madlala S: Infect One, Infect All: Zulu Youth Response to the AIDS Epidemic in South Africa. Medical Anthropology 1997, 17:363-380.

15. Maman S, Mbwambo JK, Hogan NM, et al.: HIV-Positive Women Report More Lifetime Partner Violence: Findings From a Voluntary Counseling and Testing Clinic in Dar Es Salaam, Tanzania. Am J Public Health 2002, 92(8): | $33 \mid-7$.

16. Wallman S: Risk, STD and HIV Infection in Kampala. Health, Risk \& Society 2000, 2(2):189-203.

17. Ukwuani FA, Tsui AO, Suchindran CM: Condom use for preventing HIV infection/AIDS in sub-Saharan Africa: a comparative multilevel analysis of Uganda and Tanzania. Acquired Immune Defic Syndr 2003, 34(2):203-13.

18. Brown JE, Ayowa OB, Brown RC: Dry and Tight: Sexual Practices and Potential Aids Risk in Zaire. Social Science and Medicine 1993, 37(8):989-994.

19. Gausset Q: AIDS and Cultural Practices in Africa: The Case of the Tonga (Zambia). Social Science and Medicine 200 I, 52:509-5 I8.

20. Singhal A, Usdin S, Scheepers E, Goldstein S, Japhet G: Harnessing the Entertainment-Education Strategy in Development Communication by Integrating Program Design, Social Mobilization and Advocacy. In Communication and Development in Africa Edited by: Charles Okigbo, Festus Eribo. Boston, Rowman \& Littlefield; 2004.

21. Mantel N, Haenszel W: Statistical aspects of the analysis of data from retrospective studies of disease. Journal of the National Cancer Institute 1959, 222:719-748.

22. Andersson N, Mitchell S: Epidemiological geomatics in evaluation of mine risk education in Afghanistan: introducing population weighted raster maps. International Journal of Health Geographics 2006, 5: I.

23. Walker A, Hershow C, Nicholas S: Crime in England and Wales 2005/6. 2006 [http://www.homeoffice.gov.uk/rds/pdfs06 hosb 1206.pdf]. Home Office Statistical Bulletin, London

24. Tjaden P, Thoennes N: Full Report of the Prevalence, Incidence, and Consequences of Violence Against Women. 2000 [http://www.ncirs.gov/pdffiles//72837.pdf]. U.S. Department of Justice Office of Justice Programs, National Institute of Justice, Washington DC

25. Andersson N, Ho-Foster A, Matthis J, et al:: National cross sectional study of views on sexual violence and risk of HIV infection and AIDS among South African school pupils. British Medical Journal 2004, 329:952-4.

26. Wilkinson RG: The Impact of Inequality : How to Make Sick Societies Healthier. London:Routledge; 2005

27. United Nations: Table I5: Inequality in income or expenditure. In Human Development Report United Nations Development Programme; 2006:335. Retrieved on 2 June 2007.

\section{Pre-publication history}

The pre-publication history for this paper can be accessed here:

http://www.biomedcentral.com/1472-6874/7/11/prepub
Publish with Bio Med Central and every scientist can read your work free of charge

"BioMed Central will be the most significant development for disseminating the results of biomedical research in our lifetime. "

Sir Paul Nurse, Cancer Research UK

Your research papers will be:

- available free of charge to the entire biomedical community

- peer reviewed and published immediately upon acceptance

- cited in PubMed and archived on PubMed Central

- yours - you keep the copyright
BioMedcentral 